$115 \frac{7}{2017}$ Caritos

\title{
Caritas as the Third Sector of Society in Poland Wiesław Przygoda
}

\section{Introduction}

In countries with a stabilised democracy, public activities are divided into three sectors. According to this typology, the first sector of society is public administration and it is also designated as the state or government sector. The second is sometimes called the private or economic sector and consists of the business sphere. It includes companies, institutions and organisations where activity is aimed at creating profit. The third is sometimes designated as the civic sector and consists of a variety of institutions and organisations which are not aimed at creating profit (non-profit), but at satisfying the needs of its members or realising socially beneficial goals. A typical third-sector institution is created bottom-up as a spontaneous initiative, i.e., in response to perceived social needs or problems awaiting a solution. An important factor in the birth of such an initiative usually is that the form of activity of the state or private sector in some sphere of social life is absent or unacceptable. ${ }^{1}$

Over the course of the centuries, different types of organisations, associations and foundations of the third sector have been set up in Poland which have in common the free and selfless social involvement of volunteers. At present Caritas belongs among the prominent and clearly recognisable organisations of the third sector in Poland. Between $5^{\text {th }}$ and $10^{\text {th }}$ December 2014 a public opinion poll was carried out by the research agency TNS OBOP. The results have shown that $58 \%$ of adult Poles perceive Caritas as the best-known charitable organisation in Poland. If they were to choose an organisation to which they would regularly send financial aid, then $43 \%$ of the respondents would choose Caritas. ${ }^{2}$ This shows the great trust that Polish society harbours in Caritas, which it enjoys in fulfilling its tasks at national, diocesan and parish levels. The problem addressed by this paper can be expressed in one question: what is the legal and organisational situation of Caritas as a subject of the third sector in Poland?

\section{The historical and legal conditions of charitable activities in Poland}

For centuries, a tradition of social and charitable work has existed in Poland, which has been manifested in mutual assistance and involvement in solving the problems of others. Persons acting socially were commonly designated as social workers or altruists, whereby the term 'volunteer' was unknown until the $20^{\text {th }}$ century and was not in use. ${ }^{3}$ Nonetheless, charitable activity

Tadeusz KAMIŃSKI, Kościół i trzeci sektor, Trzeci Sektor. Kwartalnik o problematyce społeczeństwa obywatelskiego 15/2008, pp. 7-9.

Cf. Działanie bez rozgłosu - wyniki badań TNS OBOP, Caritas 1/2015, p. 19.

Cf. Beata GOCKO, Aspekt społeczno-prawny wolontariatu w III Rzeczypospolitej Polskiej, Seminare 24/2007, p. 356. 
has gradually developed since the establishment of the Polish state in the $10^{\text {th }}$ century and since ecclesial structures were set up in the Polish lands. The first proponents of charitable aid were the kings, princes and bishops. Over the course of time, religious orders, diocesan priests and lay persons became involved in charitable activity. It was primarily concerned with care for the poor, the physically disabled and orphans. The activity has been inspired by trends, which then has also prevailed in other countries of Christian Europe. ${ }^{4}$ As time progressed, the 'spital' became established as an institution of social aid on the part of the religious orders, which was perceived as a house of care for the poor, the ill, the homeless and pilgrims. Fourteenth century sources mention lay persons who were performing selfless services in the leprosaria operated by religious orders on a voluntary basis. ${ }^{5}$

When Poland obtained independence in 1918, charitable activity was performed freely by various institutions. The activity was primarily animated by religious orders, charitable societies, the Caritas Union with a national headquarters and the diocesan Caritas unions, as well as new lay associations, and especially by Catholic Action since 1929, by the Apostolate of the Ill from 1930, the Marian Sodalities, and the so-called third orders. All of these subjects associated workers with a Christian inspiration or, formulated in contemporary terms, were involved in social activity and charitable aid on the principle of volunteerism.

After the Second World War, the socio-political situation in Poland changed radically, which had an impact on the social engagement of the population. By decision of the Polish communist government in 1950, the national headquarters of Caritas, as well as the diocesan Caritas unions with their properties, were placed under the control of the Lay Catholic Association 'Caritas', which was in turn controlled by the communist government. The act was carried out in contradiction to the will of the Polish Roman Catholic Church. The brutal actions of the communist officials were accompanied by a broad propaganda campaign condemning the previous leadership of Caritas's national headquarters. With respect to the new situation and the non-effectivity of the protests on the part of the Roman Catholic Church, the Polish Bishops resolved with sorrow at their plenary session on the $30^{\text {th }}$ January 1950 in Cracow to terminate the activity of the ecclesial Caritas. ${ }^{6}$ The impossibility of activity within Caritas forced the Polish church to seek alternative forms of realising the charitable function.?

The situation when the charitable activity of the Roman Catholic Church in Poland was markedly limited due to administrative barriers posed by communist officials lasted until the end of the 1980 s and had a negative impact on Catholic social engagement. On the other hand, the communist officials forced citizens to participate in common activities, which were organised for ideological reasons, especially on Sundays and Church holidays. These events were accompanied by atheistic indoctrination, their compulsory character and often poor organisation or meaninglessness of the realised projects directly contributed to the devaluation of citizens' social engagement.

4 See Wiesław PRZYGODA, Rozwój działalności charytatywnej Kościoła w Polsce, in: Teologia pastoralna, ed. Ryszard KAMIŃSKI, Lublin: Atla 2, 2000, vol. 1, pp. 468-471.

5 Maria BOCHEŃSKA-SEWERYN, Kościół katolicki w Polsce a opieka społeczna, in: Sektor pozarządowy w zmieniającym się społeczeństwie, ed. Brunon SYNAK and Miroslav RUZICA, Gdańsk - Indianapolis: Uniwersytet Gdański, Instytut Filozofii i Socjologii, Indiana University Center on Philanthropy, 1996, p. 125.

6 See Dominik ZAMIATAŁA, Caritas. Działalność i likwidacja organizacji 1945-1950, Lublin: KUL, 2000, pp. $285-329$.

7 At the national level, the Committee of the Polish Episcopate for Charity took over all of the tasks of the national Caritas headquarters concerning the coordination and inspiration of charitable activity. The then president of the Committee Cardinal A. S. Sapieha stated that in this situation the Church in Poland must perform charitable activity in the name of Christian mercy as part of everyday pastoral work and base it on the structure of dioceses and parishes, which is natural for the Church. See Czesław DOMIN, Doświadczenia Komisji Charytatywnej Episkopatu w latach 1980-1987 przygotowaniem do wznowienia działalności kościelnej „Caritas” w Polsce, Wiadomości Charytatywne 38 (1988), no. 4, p. 17. 


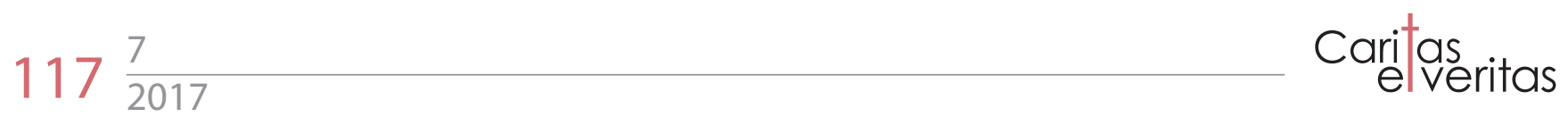

In 1980, due to the social events brought about by the independent self-governing labour union 'Solidarity', the Polish awareness of the need for social engagement grew slightly. Unfortunately, this abrupt outbreak of shared national enthusiasm was suppressed in its very beginnings by martial law, which was introduced over the whole country on $13^{\text {th }}$ December 1981 by General Wojciech Jaruzelski. Although after the suspension and later full abolition of martial law in Poland there appeared more and more symptoms of the crumbling totalitarian system and increasing signs of freedom, the path to full democracy was still to be long. That is why in this socio-cultural context volunteerism could not develop freely in Poland until the early 1990s and it was a phenomenon appearing to a much lesser extent than that in the West. ${ }^{8}$

New possibilities of developing non-profit activities in Poland appeared after the coup in 1989 and after the socio-political changes taking place at the beginning of the last decade of the 20th century. Despite numerous difficulties and great opposition, Polish society began to construct democracy and prosperity upon three pillars: a free market economy, represented through the business sector; democratically elected organs of public administration, which includes members of parliament, representatives of various levels of local government and central government officials; and volunteer civil institutions, which constitute the third sector. ${ }^{9}$ The new socio-political system contributed to the establishment of numerous non-government non-profit organisations ${ }^{10}$ and social initiatives independent of state power, which enlivened the social activity of citizens again and contributed towards volunteerism.

Although so-called social organisations also functioned in Poland in the communist period, they were not 'non-government' because they were financed from the state budget and controlled by state services. Only organisations and societies registered after 1989 became de facto non-government, because their registration was now a matter of general courts of law, their goals and regulations were merely recorded in their statutes, and they did not originate from the organs of state administration. The new organisations were encouraged to base their activity on the 'non-profit' principle. This means that all profit coming from charitable events, public means obtained for social purposes, and also from the economic activity of the organisation must be used for realising its statutory goals, which are to be useful in the social sphere. In no case is it possible to distribute the obtained means among the members or founders of the non-government organisation. ${ }^{11}$ In this way the unpaid work of volunteers became the moving force in the development of non-government organisations, ${ }^{12}$ which by their social activities encouraged new interested persons to become involved in volunteerism.

8 The weak dynamic of the development of volunteerism in Poland before 1989 was due to several causes. First, as a result of a break at the time of the communist reign, there was no tradition of volunteerism passed over from generation to generation. Another reason was the poverty of Polish society, which was forced to concentrate on finding ways of meeting basic everyday needs and there was usually no time or energy for satisfying the higher social needs. A third reason was a low level of awareness of the ways and means of social work. Cf. Beata GOCKO, Aspekt społeczno-prawny wolontariatu w III Rzeczypospolitej Polskiej, p. 358.

9 Zbigniew WEJCMAN, Świadczenie usług społecznych. Poradnik dla liderów sektora pozarządowego działaczy samorządowych, Warsaw: BORIS, 2000, p. 9.

10 Non-government organisations are often called the third sector, next to governmental institutions and the business sector, free market, enterprise. Non-government organisations, unlike the organs of public administration but like businesses, are private, created at the incentive of their founders, but, unlike businesses and like public administration organs, act not in private interest but in the public interest. Especially in international communication, another name for non-government organisations has become increasingly more popular - NGO (an abbreviation of the English 'non-governmental organisation'). See (c) Co to jest trzeci sektor? (on-line), at: www. http//osektorze.ngo.pl, accessed 6th October 2016.

11 Cf. Beata GOCKO, Aspekt społeczno-prawny wolontariatu w III Rzeczypospolitej Polskiej, p. 358.

12 By December 2014, approximately 17,000 foundations and 100,000 associations were registered in Poland. It is estimated that approximately 80,000 foundations and societies are active. Only 8,000 of these subjects have the status of a publicly beneficial society, which entitles the obtaining of $1 \%$ of natural person income tax. In 2014, around 12 million persons sent more than 500 Polish zlotys to publicly beneficial societies as part of the $1 \%$ of the natural person income tax. Cf. ๑ PORTAL ORGANIZACJI POZARZĄDOWYCH (on-line), at: http://fakty.ngo.pl, accessed 19th October 2016. 


\section{The legal foundation of the functioning of church-operated institutions in the social security system in Poland}

In the Polish social security system, institutions of all three sectors meet: the public, the market, and the non-government (civic). In the public sector, institutions of central and local government operate. The Ministry of Work, Family and Social Affairs directs and oversees the carrying out of state policy. In different regional offices, there are social policy departments. Many tasks of the social policy of the state are carried out by local government at the level of regions and municipalities. Institutions of the market sector, which are commercial subjects, fulfil tasks in the sphere of constant care for persons with a health disability, the ill, and the elderly. If commercial subjects want to operate a facility of constant care, they must meet the prescribed standards and obtain the governor's permission. Ever increasingly, tasks in the sphere of social care in Poland are performed by non-government organisations. These are, first of all, institutions, associations and foundations operating on the principle of non-profit organisations. They carry out their activity on a non-profit basis. Institutions of the Roman Catholic Church also find themselves in this sector. ${ }^{13}$

Following the Second Vatican Council the Roman Catholic Church changed its vision of its relationships with the state as a political community. The Church gave up the medieval legal vision of a homogeneous state with respect to religious confession and acknowledged the fact of a pluralist society. ${ }^{14}$ Within pluralism the Roman Catholic Church co-exists with other religious communities and with state institutions and it has given up its claims to privileges. In its relationship with the state, the Church strives to respect three principles: a) the principle of respecting the freedom of conscience and religious confession, b) the principle of mutual respect for the autonomy of the state and the Church, and c) the principle of cooperation between the state and the Church for the common good of the people. ${ }^{15}$

At present the Polish state guarantees freedom of conscience to its citizens, while to the Roman Catholic Church it guarantees the respecting of its independence and autonomy based on the concordat with the Holy See (1993) and the Polish constitution (1997). The law of $17^{\text {th }}$ May 1989 On the relationship of the state to the Roman Catholic Church in the Polish Republic (according to later changes) sets the norm for a whole number of spheres of cooperation between the state and the Roman Catholic Church for the good of Polish citizens. Polish law guarantees the status of a legal subject to the Church as a whole and to its organisational units. The Church enjoys full freedom in organising its structures and appointing ecclesial officials, as well as in the sphere of education, cult and missionary, social and charitable activity. The Church has the right to teach religion in schools and operate its own Catholic schools at all levels: from pre-school facilities up to tertiary education. Similarly, there is a legal basis for pastoral care in the army, in prisons, educational facilities, hospitals and institutions of social care. The Church can also establish associations, foundations, erect churches and monasteries and operate its own media. Marriages contrived in the Roman Catholic Church are acknowledged by the state based on the concordat. Other churches and religious societies have similar legal regulations in Poland.

13 Cf. Tadeusz KAMIŃSKI, Instytucje kościelne w polskim systemie pomocy społecznej, in: Praca socjalna w organizacja pozarządowych. Z problemów działania i kształcenia, ed. Barbara KROMOLICKA, Toruń: Wydawnictwo Edukacyjne AKAPIT, 2005, pp. 111-121.

14 Gaudium et spes 76.

15 Józef KRUKOWSKI, Kościelne prawo publiczne w Europie i Polsce, in: Kościót w życiu publicznym. Teologia polska i europejska wobec nowych wyzwań, Lublin: KUL, 2004, vol. 1, p. 415. 
The abovementioned law of $17^{\text {th }}$ May 1989 On the relationship of the state to the Roman Catholic Church in the Polish Republic defines the extent of the Roman Catholic Church's charitable activity as follows:

The charitable and caring activity of the Church primarily includes: 1) operating institutions for orphans, the elderly, persons with a bodily or mental disability and other categories of persons in need of care; 2) operating hospitals and other healthcare facilities and pharmacies; 3) organising aid in motherhood protection; 4) organising aid to orphans, persons afflicted with natural catastrophes and epidemics, victims of war, families in a difficult material or health situation and to individuals, including those dispossessed of freedom; 5) operating nurseries, kindergartens, dormitories and asylum houses; 6 ) assistance in providing recreation for children and youth in need; 7) asserting the idea of help to the neighbour and social attitudes which contribute to it; 8 ) foreign aid to victims of natural catastrophes and persons in special need (art. 39).

Subsequently the law of $12^{\text {th }}$ March 2004 On social care ${ }^{16}$ stipulates that state organs and local governments can refer tasks from the sphere of social help among others

to legal persons and organisational units operating based on the regulations concerning the relationship of the state to the Roman Catholic Church in the Polish Republic, the relationship of the state to other churches and religious societies, and based on the guarantee of freedom of conscience and religious confessions, when the goals defined in their statutes include performing activities in the sphere of social care (art. 25, para. 1, point 2).

These subjects can not only fulfil tasks in the sphere of social care, when they take part in the bidding process, but they can make such a bid on their own initiative (art. 27, para. 1). Each subject receiving permission to undertake an assignment, which also concerns ecclesial institutions, commits itself to fulfil the task to the extent and under the conditions stipulated in the contract, where the submitter is obliged to provide specific financial means in the form of a grant (art. 33, para. 1). The obtained subsidy cannot be used for other goals. In this way, the law on social care makes it possible for church institutions involved in the operation of the system and financing of social care in Poland to provide institutional care.

An important basis for the activity of church institutions in the third sector is the law of $13^{\text {th }}$ June 2003 On social employment. ${ }^{17}$ The law describes the principles of social work and refers

especially to: 1) homeless persons undertaking an individual plan of giving up homelessness, in the sense of regulations concerning social helped;2) persons addicted to alcohol;3) persons addicted to drugs or other narcotic substances; 4) persons mentally ill in the sense of regulations concerning the protection of mental health; 5) persons unemployed in the long term in the sense of regulations concerning the promotion of employment and institutions in the labour market; 6) persons released from prison who find it difficult to be integrated in society, in the sense of regulations concerning social care; 7) refugees realising an individual integration programme, in the sense of regulations concerning social care; 8) persons with a health disability, in the sense of regulations concerning work and social rehabilitation and employment of persons with a health disability who are subject to social exclusion and with respect to their life situation are incapable of meeting their basic life needs with their own

16 Dziennik Ustaw Rzeczypospolitej Polskiej 2004, no. 64, item 593.

17 Dziennik Ustaw 2003, no. 122, item 1143. 
effort and are in a situation giving rise to poverty and preventing or limiting involvement in work, social and family life (art. 1, para. 2).

According to this law, publicly beneficial organisations, which also includes church institutions with such a status, can found and operate centres of social integration (art. 3, para. 2) and organise social cooperatives employing persons social excluded or in danger of social exclusion with the financial support of the local government (art. 16, para. 1). In 2004-2014 approximately 370 social cooperatives were set up in Poland, which have given employment to more than 1,600 persons with a health disability, who are unemployed or are in danger of social exclusion. As part of the programme of social economy development in Poland, 1.4 billion Polish zloty were set apart in the state budget in 2014-2020 with the goal of creating 35,000 work places in this sector. ${ }^{18}$ Third sector organisations can also operate clubs of social integration, the activity of which has, amongst others, the goal of social and work reintegration by means of looking for work and preparing unemployed persons for work involvement in the free market (art. 18).

\section{The legal codification of the status of volunteers and publicly beneficial organisations in Poland}

The United Nations Organisation proclaimed the year 2001 as the International Year of Volunteers, which intensified public interest in volunteer activity. Not only in Poland, the topic appeared more frequently in the media and the state administration and local governments also devoted increased attention to it. It also became increasingly clear to legislators that the development of volunteerism makes it necessary to adopt adequate legal regulations in this area. For a long time, volunteerism did not have a regulated legal status in Poland. The first legal norms regulating the providing of services on a volunteer basis had appeared in the law of $29^{\text {th }}$ November 1990 On social security ${ }^{19}$ and in the Directive of the minister of work and social politics concerning educational and custodial centres of $1^{\text {st }}$ September $2000 .{ }^{20}$ These legal acts regulated the involvement of volunteers only in centres of care for children and in family foster care. However, there still remained broad spheres of social work, such as, for example, hospitals, rehabilitation centres for persons with a health disability, hospices, cultural centres, volunteer centres, charitable institutions, ecological organisations, etc., in which volunteer work was very much needed and complex legal regulations were still missing for them.

After a period of intensive reminding of this fact on the part of Polish non-government organisations, in 2002 volunteerism became a topic of the proceedings of the Polish parliament. After a year of discussions and work in parliamentary committees, the Sejm of the Republic of Poland on $24^{\text {th }}$ April 2003 passed the Law on publicly beneficial activity and volunteerism ${ }^{21}$ and the Implementing regulations of the law on publicly beneficial activity and volunteerism. ${ }^{22}$ The two legal acts introduced system changes in the functioning of civic society and play a significant part in constructing democracy in Poland. ${ }^{23}$

18 Jakub SUKIENNIK, Spółdzielnie socjalne - dobry początek, Caritas 1/2015, p. 18.

19 Dziennik Ustaw 1998, no. 64, item 414. This act was abolished by the new law on social care of $12^{\text {th }}$ March 2004.

20 Dziennik Ustaw 2000, no. 80, item 900. This is the currently valid regulation of the Ministry of Work and Social Policy of $14^{\text {th }}$ February 2005 concerning educational and custodial centres, Dziennik Ustaw 2005, no. 37, item 331.

21 Dziennik Ustaw 2003, no. 96, item 873 [changes of $12^{\text {th }}$ March 2010, Dziennik Ustaw 2010, no. 28, item 146].

22 Dziennik Ustaw 2003, no. 96, item 874. This legal act changed the rules of twenty legal norms in order to adjust them to the regulations of the Law on publicly beneficial activity and volunteerism.

23 See Hubert IzdebSki, Ustawa o działalności pożytku publicznego i o wolontariacie. Komentarz, Warsaw: Ministerstwo Gospodarki, Pracy i Polityki Społecznej, 2003; Henryk Cioch, Organizacje pożytku publicznego i wolontariat - nowe regulacje prawne, Rejent 10/2003, 
The Law on publicly beneficial activity and volunteerism, which became valid on $29^{\text {th }}$ June 2003 and was last amended on $12^{\text {th }}$ March 2010, defines the legal status of volunteers and the organisational and formal aspects of their activity. According to article 2, paragraph 3 of the law, a volunteer is a physical person who freely and without claim to a reward performs a service in accordance with the principles of publicly beneficial activity, i.e., socially useful activity operated by non-government organisations in the sphere of public tasks. According to the law, a volunteer is not only a person performing a service for non-government organisations, but also for organs of public administration and subordinate units, with the exception of economic activity (art. 42). A member of an association can perform a service as a volunteer also in the association of which he is a member.

The law emphasises that volunteers involved in publicly beneficial activity must be qualified for the given type and extent of services provided, if the obligation to such a qualification and meeting the relevant requirements is implied by special regulations (art. 43). The services ought to be performed based on the conditions stipulated in the agreement between the volunteer and the subject making use of his services. The agreement ought to contain a provision concerning the possibility of dissolving it (art. 44, para. 1). If volunteer services are performed for more than 30 days, then the agreement must be in writing (art. 44, para. 4). At the volunteer's request, the other party is obliged to provide a written confirmation of the agreement even for a shorter period of commitment, as well as present a written statement of the services performed by the volunteer (art. 44, paras. 2 and 3).

According to the law of $24^{\text {th }}$ April 2003, a volunteer is not a worker in the sense of labour law regulations, which implies that the other party making use of his services is not his employer. However, in some respects the situation of a volunteer is described in terms analogous to the status of a worker. ${ }^{24}$ A subject making use of the services of a volunteer is, among other things, obliged to inform him of the health and security risks associated with performing the service and with the principles of threat protection. Further, such a subject ought to secure safe and hygienic conditions for the volunteer to perform the service in, and, if necessary, also suitable personal protection equipment. A subject making use of the services of a volunteer is obliged to meet the costs associated with service-related trips and the related expenses, as in the case of an employee (art. 45, para. 1, points 1-3). Besides these obligations, a subject making use of the services of a volunteer can also meet the volunteer's other necessary expenses related to performing services for the recipients, especially the costs of the training necessary for performing the services stipulated in the agreement (art. 45, paras. 2-3).

The Law on publicly beneficial activity and volunteerism stipulates that volunteers performing a service for a period longer than 30 days receive compensation in case of an accident based on special regulations, ${ }^{25}$ assuming that a written agreement exists between the service provider and the volunteer providing the help (art. 46, para. 2). If the service is performed for a period shorter than 30 days, the subject making use of the volunteer's services is obliged to provide him with insurance against the consequences of an injury (art. 46, para. 3). A volunteer can be entitled to healthcare, based on principles stipulated in regulations concerning healthcare services financed

pp. 11-26; Radosław Skiba, Ustawa o działalności pożytku publicznego i o wolontariacie, Warsaw: Fundacja Rozwoju Demokracji Lokalnej, 2004; Artur GLuziński, Ustawa o działalności pożytku publicznego i o wolontariacie, Warsaw: Difin, 2005; Jerzy Kopyra, Ustawa o działalności pożytku publicznego i wolontariacie: komentarz, Warsaw: C. H. Beck, 2005.

24 Cf. Beata GOCKO, Aspekt społeczno-prawny wolontariatu w III Rzeczypospolitej Polskiej, p. 363.

25 The law of $30^{\text {th }}$ October 2002 concerning compensations in case of vocational injury or illness arisen under specific circumstances (Dziennik Ustaw 2002, no. 188, item 1674 with later amendments). 
from public funds (art. 46, para. 1). Besides that, the subject making use of the volunteer's services can provide him with insurance against civil responsibility for damage arisen in the course of performing the service (art. 46, para. 6).

The law states various public tasks that may be realised through non-government organisations (art. 4, para. 1). According to the law on publicly beneficial activity mentioned above, these tasks can be performed, besides other non-government organisations, also through the legal person and administrative unit of the Roman Catholic Church. In accordance with the Church's mission, these are primarily the following public tasks:

- social assistance to families and persons in a difficult life situation;

- activity for the work and social integration and reintegration of persons in danger of social exclusion;

- charitable activity;

- activity for persons with a health disability;

- activity for elderly persons;

- protecting and spreading national traditions;

- protection and promotion of health;

- promotion of the employment and work activation of unemployed persons;

- schooling, education, further education and upbringing;

- travel and recreation of children and youth;

- culture, art, and protection of culture and art;

- promotion of physical education and sport;

- prevention of addictions and socio-pathological phenomena;

- help to victims of catastrophes, natural disasters, armed conflicts;

- promotion and organisation of volunteerism.

According to the law of $23^{\text {rd }}$ April 2003, ecclesial legal persons can apply for the status of a publicly beneficial society. For this purpose, they must meet the requirements concerning publicly beneficial societies with respect to article 20 of the law and be registered in the National Court Register. Registration is carried out in the way and under the conditions stipulated in the law of $20^{\text {th }}$ August 1997 on the National Court Register. ${ }^{26}$ Registration is constitutive in character, which means that without it no non-government organisation can appeal to this status, even if it meets all of the conditions stipulated by the law. A subject that meets the conditions stipulated by the law is not obliged to obtain the status of a publicly beneficial society. But a register court cannot assign such a status based only on its authority. If an organisation wants to obtain the status of a publicly beneficial society, it must apply for registration at the appropriate regional court, which operates a department of the National Court Register. ${ }^{27}$

The status of an organisation with publicly beneficial activity gives rise to liberation from legal entity income tax, immovable property tax, civil activities tax, and also from stamp duty tax and court taxes. It further gives the right to apply for writing off of $1 \%$ of the natural person income tax in the annual natural person income tax statement (art. 27). It must be observed that, among the most important advantages implied by obtaining the status of an organisation with a publicly beneficial activity, it is the creating of a positive image and the increase in the organi-

26 Dziennik Ustaw 2001, no. 17, item 209, no. 110, item 1189; 2002, no. 1, item 2, no. 113, item 984; 2003, no. 49, item 408, no. 60, item 535.

27 Andrzej CEGLARSKI, Organizacje pożytku publicznego, Warsaw: LexisNexis, 2005, pp. 20-21. 
sation's prestige which are the inestimable values that can be well used to gain tangible benefits, including financial ones. ${ }^{28}$

The status of an organisation with publicly beneficial activity does not bring only advantages as there are also obligations associated with it which must be kept in mind. The obligations were introduced with respect to the greater transparency of these organisations' activity. The unambiguous and transparent character of activities performed by publicly beneficial societies is regarded as one of the main principles of the law. ${ }^{29}$ An important obligation is to meet all of the legal requirements necessary for obtaining the status of a generally beneficial society. The organisation must operate in accordance with these requirements throughout the time of its activity. One of the most difficult obligations is producing an annual report about the activity of the publicly beneficial society (with respect to special regulations) and publishing it in a way which makes it possible for all parties concerned to become acquainted with its contents. ${ }^{30}$

\section{Conclusion}

In conclusion, it is necessary to emphasise that the Church focuses primarily on extra-worldly and transcendental goals and it is difficult to include it as a whole in the third sector. However, a number of its institutions belong in the sector of social activities and precede or support the state in solving complex social problems. At present, the Church in Poland operates more than 800 charitable institutions carrying out more than 5,000 charitable activities of different kinds. These institutions are directed by dioceses, female and male religious orders, parishes, and also by foundations and societies. More than 30,000 workers are involved in the charitable institutions' works of mercy. Among these are priests, consecrated persons and lay persons who together with 80,000 volunteers work in Church-operated hospices and dormitories, distribute food, take care of children, the elderly, and of persons suffering from an addiction or a health disability. By means of financial support the whole Church participates in their service of mercy and expends its assistance to more than three million persons in need. ${ }^{31}$ In the already sufficiently developed network of non-governmental organisations carrying out work in the sphere of social security, the ecclesial organisation Caritas stands out, performing many valuable initiatives at national, diocesan, parish and school level, with the goal of material, mental, social and spiritual support of human beings in need. The volunteers of Caritas significantly reinforce the tissue of social bonds and give back hope to many lost people, together with a sense of a civic society.

30 Sławomir FUNDOWICZ, Prowadzenie działalności pożytku publicznego w świetle Ustawy z dnia 24 kwietnia 2003 roku o działalności pożytku publicznego i wolontariacie, in: Miłość na nowo odkryta. Wokół Benedykta XVI encykliki o Bogu-Miłości, ed. Wiesław PRZYGODA and Jerzy KARBOWNIK, Skarżysko-Kamienna: Sanktuarium Matki Bożej Ostrobramskiej, 2007, p. 190.

31 C Polish Bishops Conference, List pasterski o posłudze charytatywnej w Roku Miłosierdzia, 15th April 2016 (on-line), at: http:// episkopat.pl, accessed 19th October 2016. 


\title{
Caritas as the Third Sector of Society in Poland
}

\begin{abstract}
In contemporary Poland, there are a number of institutions focusing on social work, which can be classified in the so-called civic sector. Among the church-operated organisations using the services of volunteers, the Roman Catholic Caritas plays a key part. The paper discusses its legal and organisational situation. First it describes the oppressive period of the second half of the 20th century, when social work in Poland was directly controlled by the communist government. It then captures the legal foundation for the functioning of church-operated institutions in the social security system in democratic Poland. The last topic is the codification of the status of volunteers and of publicly beneficial organisations. Volunteers cooperating with the Roman Catholic Caritas are one of the key factors of the systematic material, mental, social and spiritual support of the human being in need.
\end{abstract}

Keywords: Caritas, volunteerism, legislature, Roman Catholic Church, Poland, civic social sector

\section{Author contact}

dr hab. Wiesław Przygoda, prof. KUL John Paul II Catholic University in Lublin Al. Racławickie 14, 20-950 Lublin, Poland przygoda@kul.lublin.pl 